\title{
Summer Pruning as a Method for Reducing Flyspeck Disease on Apple Fruit
}

\author{
Daniel R. Cooley, Assistant Professor, James W. Gamble, Research Technician, Department of Microbiology, and \\ Wesley R. Autio, Associate Professor, Department of Plant \& Soil Sciences, University of Massachusetts, Amherst, \\ MA 01003
}

\begin{abstract}
Cooley, D. R., Gamble, J. W., and Autio, W. R. 1997. Summer pruning as a method for reducing flyspeck disease on apple fruit. Plant Dis. 81:1123-1126.

Summer pruning of apples, as opposed to the conventional commercial practice of dormant pruning, consistently reduced the incidence of flyspeck on apple fruit by approximately $50 \%$ in each of 2 years in trees where no fungicides were applied. In commercial orchard blocks using fungicides, summer pruning also produced a slight but significant decrease in disease severity. There appear to be at least two mechanisms contributing to decreased flyspeck incidence and severity in summer-pruned apple trees. Summer pruning resulted in a small change in the apple canopy microclimate, decreasing the hours of relative humidity $>95 \%$ in the canopy by $63 \%$ and increasing the evaporative potential. Summer pruning also resulted in improved spray deposition in the upper two-thirds of the tree canopy when applications were made with an airblast sprayer.
\end{abstract}

Additional keywords: cultural control, integrated pest management, plant canopy

Flyspeck (caused by Zygophiala jamaicensis E. Mason; teleomorph, Schizothyrium pomi [Mont. \& Fr.] Arx) is an important disease of apples (Malus $\times$ domestica Borkh.) throughout the eastern United States (17). Flyspeck incidence in this region generally decreases from south to north (5), although significant flyspeck damage occurs in New England. In production systems that minimize fungicide use, such as those based on scab-resistant apple cultivars, summer diseases including flyspeck can be a significant problem (15).

For many years, field observations have associated flyspeck incidence with rain, in particular late-season rain $(9,10)$ and with $\mathrm{RH}>95 \%$ (16). After $24 \mathrm{~h}$ of incubation at $20^{\circ} \mathrm{C}$, germination of ascospores of $S$. pomi was 100,67 , and $0 \%$ at 98.1, 97.1, and $96.2 \% \mathrm{RH}$, respectively (13). In the same study, conidia of the fungus were incubated at $20^{\circ} \mathrm{C}$ for $20 \mathrm{~h}$, and 98,29 , and $0 \%$ germinated at $99.7,97.1$, and $96.2 \% \mathrm{RH}$, respectively. Other important developmental activities, such as conidiophore production and substrate colonization, did not occur below $95 \% \mathrm{RH}$ at 20 or $28^{\circ} \mathrm{C}$. The optimum growth temperature of the fungus was between 20 and $24^{\circ} \mathrm{C}$. These data suggest that the fungus develops only at the highest RH.

Plant canopy microclimate can have an impact on plant diseases $(7,8,18)$. Several

Corresponding author: D. R. Cooley

E-mail: dcooley@microbio.umass.edu

Accepted for publication 4 June 1997.

Publication no. D-1997-0811-01R

(C) 1997 The American Phytopathological Society authors have observed that flyspeck often is more severe in unpruned apple trees than in pruned ones and have suggested that pruning improves drying in the apple canopy and can be used to reduce flyspeck incidence $(2,11,12)$. However, tests on the effect of dormant pruning on flyspeck in North Carolina showed that pruning had no effect in 2 years and actually increased flyspeck in a third (14). While it seems sound to recommend pruning as a way to improve both drying in the apple canopy and spray penetration, to our knowledge no controlled studies have supported this assertion, and no studies have examined the effect of pruning, particularly summer pruning, on flyspeck in the Northeast.

Summer pruning of apples is a relatively new horticultural practice used to accelerate and improve fruit coloration of apples in New England (4). This pruning usually is done after trees have set terminal buds and is designed to increase light penetration in canopies by removing vegetative growth in the tops and outside edges of tree canopies. The purpose of this study was to determine whether summer pruning has an effect on flyspeck incidence in the Northeast, and if so, to try to determine how changes in canopy architecture might be causing the effect.

\section{MATERIALS AND METHODS}

Trials were performed both in orchards owned by the University of Massachusetts and in commercial orchards in Massachusetts, using mature trees of the cultivar McIntosh, on M.7 rootstocks that had received normal dormant pruning the previous winter. Standard summer pruning recommendations (4) were followed after terminal buds had formed, in early to mid July. This involved cutting out smaller branches, no larger than $2.5 \mathrm{~cm}$ in diameter. Vigorous, upright branches, including watersprouts, were removed, as well as weak branches that were shading more productive branches.

Summer pruning without summer fungicide applications. In 1991, an experiment was done at the Horticultural Research Center, Belchertown, MA, using 14 mature McIntosh trees that were approximately $5 \mathrm{~m}$ tall and $4 \mathrm{~m}$ wide, spaced $6.1 \times 7.4 \mathrm{~m}$ on M.7 rootstock. Trees were randomly assigned to one of two treatments, summer-pruned or non-pruned controls. Fenarimol (Rubigan E.C., 12\% a.i., mixed at $0.31 \mathrm{ml}$ of formulation/L) was applied to the block four times prior to 15 June to control apple scab; no fungicides were applied thereafter. Trees were pruned on 9 July.

S. pomi cosmetically damages fruit by producing stromata in discrete groups or colonies. The stromata are each approximately $0.5-1.0 \mathrm{~mm}$ in diameter and may develop into pseudothecia. Flyspeck severity was rated when fruit reached commercial harvest maturity (19 September) by examining 50 fruit per tree, selected arbitrarily, and counting the number of individual stromata on each fruit. Commercial damage was also evaluated using USDA grade standards (3) as follows: Extra Fancy fruit have no more than 5\% of the surface covered by flyspeck, or dark, heavily concentrated spots that affect an area no more than $6.35 \mathrm{~mm}$ in diameter; Fancy and No. 1 fruit have no more than $10 \%$ of the surface covered by flyspeck, or dark, heavily concentrated spots that affect an area no more than $12.7 \mathrm{~mm}$ in diameter; and Utility fruit have no more than $33 \%$ of the fruit surface covered. The number of fruit downgraded from the highest grade (Extra Fancy) as a result of flyspeck damage was recorded. Means of incidence and commercial damage in each treatment were compared using an independent $t$ test. In 1992, the experiment was repeated on the same site in a similar block of McIntosh trees, with pruning done on 16 July and fruit evaluation done on 15 September.

Summer pruning and fungicide interactions. In 1991, a block of trees at the University of Massachusetts Horticultural Research Center (Belchertown, MA) was selected to test the effect of summer pruning and a single fungicide application in a factorial experiment. Trees were spaced at 

wide. Prior to the summer fungicide treatments, the block received four applications of fenarimol (Rubigan E.C., 12\% a.i., mixed at $0.31 \mathrm{ml}$ of formulation/L) applied with a handgun to runoff to control apple scab. Within the block, three replicates of in a $2 \times 3$ factorial design in which three trees in each replicate were randomly selected and summer pruned and three were not pruned. Within each pruning treatment, one tree was treated with captan (50WP) at $0.53 \mathrm{~g}$ of formulation/L plus benomyl (50WP) at $0.20 \mathrm{~g}$ of formulation/L; one tree was treated with captan only at $0.53 \mathrm{~g}$ of formulation/L; and one tree was not treated with a fungicide. Summer pruning were applied once on 21 July using a handgun sprayer to cover the foliage until runoff. Flyspeck was evaluated on 100 fruit per tree on 1 September. Disease incidence was scored by counting the number of fruit on which flyspeck was severe enough to reduce fruit grade from USDA
$6.1 \times 7.4 \mathrm{~m}$ and were $3-4 \mathrm{~m}$ tall and 3-4 m six adjacent trees were assigned treatments was done on 13 and 14 July, and fungicides

Extra Fancy, and disease severity was scored by counting the number of colonies on each fruit. Data were analyzed using a complete factorial analysis of variance, and appropriate means were separated using Tukey's HSD test.

Summer pruning and flyspeck incidence in commercial orchard blocks. In 1992 and 1993, eight commercial apple orchards in different locations in Massachusetts were used to test the effects of summer pruning on flyspeck. In each, a set of 10 adjacent McIntosh trees in a single row were summer pruned in late July to early August. A second set of 10 adjacent McIntosh trees was left as unpruned checks. Initial tree size and tree density varied by block, but all trees were mature on either M.7 or seedling rootstocks, ranging from 3 to $5 \mathrm{~m}$ tall and from 3 to $4.5 \mathrm{~m}$ wide. Growers were asked to minimize fungicide applications after 15 June in the blocks, but choice of fungicide and application timing were at the growers' discretion. In early September, fruit from these trees were harvested, 20 from each of

Table 1. Effect of summer pruning on flyspeck incidence and severity on mature, semi-dwarf McIntosh apple trees in 1991 and 1992

\begin{tabular}{lcccc}
\hline Year & $\begin{array}{c}\text { Summer } \\
\text { pruning }\end{array}$ & $\begin{array}{c}\text { Percent fruit } \\
\text { with colonies }\end{array}$ & $\begin{array}{c}\text { Avg. no. of stro- } \\
\text { mata/fruit }\end{array}$ & $\begin{array}{c}\text { Percent reduction from Ex- } \\
\text { tra Fancy to a lower grade }\end{array}$ \\
\hline 1991 & Pruned & $9.4^{\mathrm{z}}$ & 57.1 & 3.3 \\
& Not pruned & 18.0 & 229.9 & 12.1 \\
1992 & Pruned & 35.3 & 87.3 & 4.7 \\
& Not pruned & 64.2 & 291.2 & 20.2 \\
\hline
\end{tabular}

${ }^{\mathrm{z}}$ Means are expressed for all fruit in the treatment and are significantly different within each year by a $t$ test at $P \leq 0.05$.

Table 2. Flyspeck incidence and severity on summer-pruned and non-summer-pruned trees treated once with captan + benomyl, captan alone, or no fungicide

\begin{tabular}{lccccccc}
\hline & \multicolumn{3}{c}{ Fruit with flyspeck, \% } & & \multicolumn{3}{c}{ Disease severity (colonies/fruit) } \\
\cline { 2 - 3 } \cline { 7 - 8 } Fungicide & Not pruned & Pruned & Mean $^{\mathbf{z}}$ & & Not pruned & Pruned & Mean \\
\hline None & $43.6^{*}$ & 30.3 & $37.0 \mathrm{a}$ & & $4.2^{*}$ & 2.3 & $3.2 \mathrm{a}$ \\
Captan & $24.4 \mathrm{~ns}$ & 18.9 & $21.7 \mathrm{~b}$ & & $2.0 \mathrm{~ns}$ & 1.7 & $1.9 \mathrm{~b}$ \\
Captan + Benlate & $25.8^{*}$ & 13.3 & $19.6 \mathrm{~b}$ & & $1.5 \mathrm{~ns}$ & 1.4 & $1.4 \mathrm{~b}$ \\
\hline
\end{tabular}

${ }^{\mathrm{x}}$ Flyspeck severity sufficient to cause a fruit to be downgraded from USDA Extra Fancy.

${ }^{\text {y }}$ For each type of disease evaluation, means for pruned and non-pruned trees in each fungicide treatment were compared using an $F$ test and are siginificantly different if followed by an asterisk $(P \leq 0.05)$.

${ }^{\mathrm{z}}$ Means in each fungicide treatment were compared using Tukey's HSD $(P \leq 0.05)$ and are significantly different from each other if followed by different letters.

Table 3. Flyspeck incidence in 10 commercial apple orchards in Massachusetts on fruit from summer-pruned trees and trees that were not summer-pruned in terms of USDA grades

\begin{tabular}{cccccc}
\hline & & & & \multicolumn{2}{c}{$\begin{array}{c}\text { Percent fruit in grade } \\
\text { with respect to flyspeck }\end{array}$} \\
\cline { 3 - 6 } Year & $\begin{array}{c}\text { Summer fungicide } \\
\text { applications }\end{array}$ & $\begin{array}{c}\text { Summer } \\
\text { pruning }\end{array}$ & $\begin{array}{c}\text { Flyspeck incidence } \\
(\mathbf{\%})^{\mathbf{y}, \mathbf{z}}\end{array}$ & $\begin{array}{c}\text { Extra } \\
\text { Fancy }^{\mathbf{z}}\end{array}$ & Fancy $^{\mathbf{z}}$ \\
\hline 1992 & 3.2 & No pruning & $7.5^{*}$ & $99.5^{*}$ & $0.5^{*}$ \\
& \multirow{2}{*}{1.5} & Pruning & $5.3^{*}$ & $99.8^{*}$ & $0.2^{*}$ \\
& & No pruning & $5.8^{*}$ & $99.5^{*}$ & $0.5^{*}$ \\
& & Pruning & $3.1^{*}$ & $99.9^{*}$ & $0.1^{*}$ \\
\hline
\end{tabular}

${ }^{x}$ Mean number of fungicide applications applied after 15 June in the blocks.

${ }^{y}$ Any flyspeck incidence regardless of amount.

${ }^{\mathrm{z}}$ For each grade in each year, percentages followed by asterisks indicate a significant difference at $P$ $\leq 0.05$ by Tukey's HSD test. Data were transformed using an arcsine transformation prior to analysis. four quadrants inside each tree. Similar sampling was done from a set of nonpruned trees in the same block. After cold storage for 45 days, the fruit were scored for flyspeck incidence. They were rated as Extra Fancy, Fancy, or Utility according to USDA grade standards for flyspeck severity, and fruit showing any flyspeck incidence were counted. Data were transformed using an arc sine transformation before performing analysis of variance and mean separation using Tukey's HSD test $(P=0.05)$.

Microclimate differences in summerpruned trees. In 1992, a set of eight mature McIntosh trees on M.7 rootstocks were monitored for temperature, $\mathrm{RH}$, and leaf wetness in their canopies. Trees were divided into four blocks of two trees, and one tree of each pair was randomly selected and summer pruned on 7 July. An electronic data recorder (Easy Logger 900, Omnidata, Inc., Ogden, UT) was connected to a combined $\mathrm{RH} /$ temperature probe (Phys/Chem supplied by Omnidata) and a leaf wetness grid (Omnidata) hung in each tree. Probes were placed as near to $2 \mathrm{~m}$ from the ground and $1 \mathrm{~m}$ from the trunk as possible, on the north side of each tree. RH/temperature probes were shielded using sections of PVC pipe, one within another, with holes drilled along the pipe to allow adequate air circulation while shielding the sensor from rain, radiation, and excessive wind. Leads from the recorder to the sensors were run through flexible PVC pipe with ends sealed to protect wires from moisture. Data from each sensor were sampled at 15-min intervals, and hourly averages for each probe were recorded from 10 July to 18 September.

A spherical atmometer (C \& M Meteorological Supply, Colorado Springs, CO) was also hung in each tree adjacent to the probes to measure evaporation in the canopy. Atmometers are ceramic containers that are slowly permeable to water and are used to estimate evapotranspiration (1). The atmometer bulbs were placed in tree canopies and supplied with deionized water using 250-ml glass bottle reservoirs, which were shielded from light and mechanical damage by a plastic foam container. The amount of water evaporated from each container was recorded at several intervals over the observation period and corrected using the correction factor supplied with each unit.

Fungicides were not applied after the equipment was placed in the trees (7 July). Flyspeck incidence was evaluated on 100 fruit selected randomly from each tree on 18 September.

Spray deposition in summer-pruned trees. In this experiment, 10 mature apple trees (McIntosh on M.7 spaced $6 \times 9 \mathrm{~m}$, 4.5-5 $\mathrm{m}$ tall and 3.5-5 $\mathrm{m}$ wide) were randomly assigned to five blocks of two trees each. In each block, one tree was summer 
pruned using standard commercial practices on 19 to 20 July 1994 and one tree was not pruned. One week later, 12 watersensitive paper targets $(2.5 \times 7.5 \mathrm{~cm})$ were systematically attached to twigs in each tree using two location factors-height and distance from canopy edge. Four targets were placed at each of three heights: lower ( $1.5 \mathrm{~m}$ from the ground), mid- $(2.5 \mathrm{~m})$, and upper canopies $(3.5 \mathrm{~m})$. At each height, two targets were placed outside the canopy (within $10 \mathrm{~cm}$ of the edge of the canopy), and two targets were placed inside the canopy (within $25 \mathrm{~cm}$ of the tree trunk). Water was applied to trees using a com- mercial airblast sprayer delivering 1,305 $\mathrm{L} / \mathrm{ha}$ and traveling at $4 \mathrm{~km} / \mathrm{h}$. Resulting spray deposition patterns on the papers were digitized directly from the watersensitive paper using a flatbed scanner (Hewlett-Packard, Palo Alto, CA). Digitized images were analyzed using public domain image analysis software (NIH Image 1.55) on a standard personal computer (Apple Computer, Inc., Cupertino, CA). Data were analyzed by computing the water-darkened area as a percentage of a uniform area $(25 \times 40 \mathrm{~mm})$ of each target. Means were separated using Tukey's HSD test.

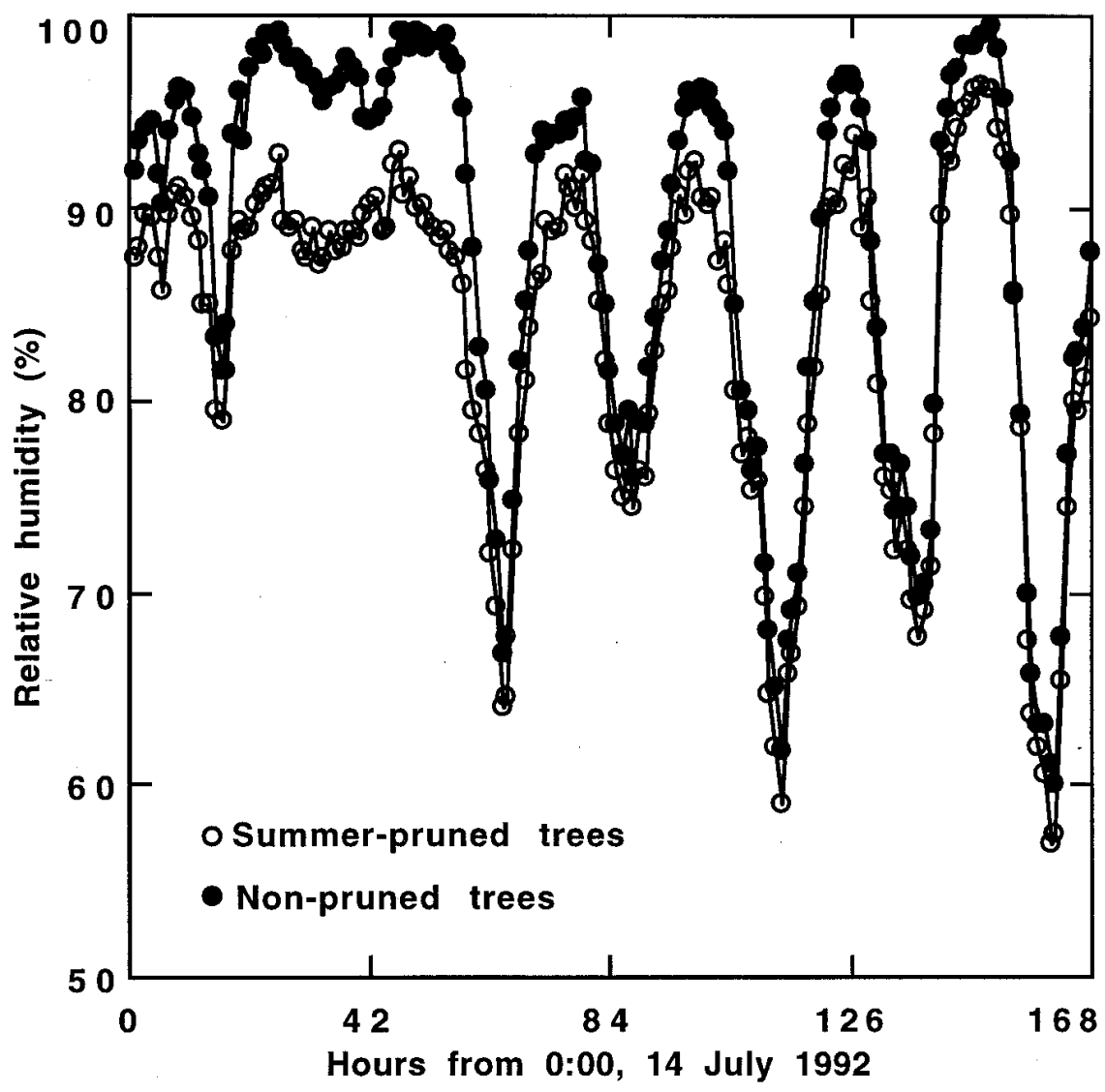

Fig. 1. Effect of summer pruning on relative humidity measured in canopies of apple trees. Each line represents the mean relative humidity of four trees measured over a 1-week period at Belchertown, MA, in July 1992.

Table 4. Evaporation from spherical atmometers and hours of relative humidity above $95 \%$ for summer-pruned and non-pruned apple trees for nine 7-day periods, 1992

\begin{tabular}{lccccc}
\hline & \multicolumn{2}{c}{ Evaporation, $\mathbf{~ m l}^{\mathbf{z}}$} & & \multicolumn{2}{c}{$\mathbf{R H} \mathbf{\mathbf { 9 5 } \%}, \mathbf{h}^{\mathbf{z}}$} \\
\cline { 2 - 3 } \cline { 5 - 6 } Period & Pruned & Control & & Pruned & Control \\
\hline 14-20 July & 55.4 & 35.7 & & $22^{*}$ & 63 \\
21-27 July & $110.6^{*}$ & 78.2 & & $18^{*}$ & 58 \\
28 Jul-3 Aug & $127.3^{*}$ & 90.8 & & $17^{*}$ & 49 \\
4-10 Aug & $26.5^{*}$ & 10.8 & & $26^{*}$ & 66 \\
11-17 Aug & $11.6^{*}$ & 3.1 & & $28^{*}$ & 78 \\
18-24 Aug & $100.6^{*}$ & 77.2 & & $20^{*}$ & 59 \\
25-31Aug & $120.0^{*}$ & 88.8 & & $15^{*}$ & 32 \\
1-7 Sept & 64.3 & 51.7 & & $28^{*}$ & 66 \\
8-14 Sept & $79.0^{*}$ & 61.7 & & $22^{*}$ & 60 \\
Total & $695.3^{*}$ & 498.0 & & $196^{*}$ & 531 \\
\hline
\end{tabular}

${ }^{\mathrm{z}}$ An asterisk next to the mean in the column for pruned trees indicates that the means for that period are signficantly different from the non-pruned treatment by a $t$ test at $P \leq 0.05$.

\section{RESULTS}

Summer pruning without summer fungicide applications. In trees that did not receive any summer fungicides, summer pruning reduced flyspeck incidence, and fruit that were infected had significantly fewer fungal stromata than did controls (Table 1). Flyspeck incidence was reduced from 18.0 to $9.4 \%$ in 1991 and from 64.2 to $35.3 \%$ in 1992 . Significantly fewer fruit from summer pruning treatments were downgraded as a result of flyspeck damage. Mean severity and incidence of non-pruned and pruned trees in each year were compared using a $t$ test, and differences were significant at $P \leq 0.05$.

Summer pruning and fungicide interactions. Data were analyzed using a fully factorial analysis of variance. Either of the main factors, fungicide treatment or summer pruning, were significant by an $F$ test ( $P=0.000$ and 0.007 , respectively). The interaction between fungicide application and summer pruning was significant $(P=$ $0.004)$, so the simple means within each fungicide treatment were compared using an $F$ test.

Summer pruning significantly decreased flyspeck incidence and severity where no fungicides were used (Table 2). Summer pruning also reduced flyspeck incidence where captan plus benomyl was applied. However, summer pruning did not reduce flyspeck severity where fungicides were used nor incidence where captan alone was used. Both fungicide treatments reduced flyspeck incidence and severity.

Summer pruning and flyspeck incidence in commercial orchard blocks. Summer pruning in commercial orchards, regardless of fungicide treatment, significantly reduced the amount of flyspeck (Table 3). Summer pruning decreased the percentage of fruit downgraded from Extra Fancy from 0.5 to $0.2 \%$ in 1992 and 0.5 to $0.1 \%$ in 1993 , which were small but significant differences $(P \leq 0.05)$.

Microclimate differences in summerpruned trees. The average hourly $\mathrm{RH}$ was significantly lower in the summer-pruned trees $(P \leq 0.001)$. Although the overall difference of $4.6 \%$ was relatively small, differences were most pronounced at higher RH but when leaves were not wet. For example, during the week of 14-20 July, when RH exceeded $90 \%$ in nonpruned trees, it was up to $10 \%$ lower in pruned trees, whereas the difference between the two treatments was less pronounced at lower RH (Fig. 1). From 14 July to 14 September, the RH in the nonpruned trees exceeded $95 \%$ for $531 \mathrm{~h} \mathrm{com-}$ pared to $196 \mathrm{~h}$ in summer-pruned trees, a $63 \%$ reduction (Table 4 ). The evaporative potential was also significantly lower in the non-pruned trees, as evidenced by the atmometer data $(P=0.04)$. The hours of RH above $95 \%$ and the amount of evaporation from the atmometers was significantly correlated, $r=-0.57(P=0.01)$. 
Table 5. Percent coverage of paper targets placed at set positions in summer-pruned and non-pruned apple trees

\begin{tabular}{lccc}
\hline & \multicolumn{2}{c}{ \% Coverage } & \\
\cline { 2 - 3 } $\begin{array}{l}\text { Target } \\
\text { height (m) }\end{array}$ & $\begin{array}{c}\text { Summer } \\
\text { pruned }\end{array}$ & $\begin{array}{c}\text { Not } \\
\text { pruned }\end{array}$ & Mean $^{\mathbf{z}}$ \\
\hline 1.5 & 78 & 75 & $77 \mathrm{a}$ \\
2.5 & $59^{*}$ & 35 & $47 \mathrm{~b}$ \\
3.5 & $42^{*}$ & 27 & $34 \mathrm{~b}$ \\
\hline
\end{tabular}

${ }^{\mathrm{y}}$ Means of summer-pruned vs. non-pruned trees were significantly different at $P \leq 0.05$ at each height if followed by an asterisk.

${ }^{\mathrm{z}}$ In the column means followed by different letters are significantly different at $P \leq 0.05$.

Flyspeck incidence was also associated with summer pruning and was significantly lower in the summer-pruned trees, 2.6 versus $4.9 \%$ in the controls. However, the humidity and evaporative differences were not reflected in leaf wetness or temperature readings, which were not significantly different between the pruning treatments.

Spray deposition in summer-pruned trees. Percent area wetted by spray deposition was increased by $30 \%$ with summer pruning $(P=0.01)$. The major increase in deposition came in targets placed at $2.5 \mathrm{~m}$ and higher (Table 5). The difference between the inner and outer canopy was not significant.

\section{DISCUSSION}

Summer pruning reduces flyspeck in both controlled and commercial conditions. In trees where no fungicides were used, disease incidence was reduced approximately by half in each of 2 years. It is apparent from this research and similar studies (6) that summer pruning alone generally will not control flyspeck at commercially acceptable levels. Still, summer pruning can significantly reduce flyspeck incidence on apples.

Higher RH has been associated with greater flyspeck incidence for many years $(9,16)$. Yet, while several authors have suggested that pruning will reduce humidity in apple canopies and reduce flyspeck, a controlled experiment in North Carolina failed to support the suggestion (14). In contrast, our research consistently indicates that summer pruning reduces flyspeck on apples. The difference may be explained by two factors. First, flyspeck is a severe endemic yearly disease problem in the southeastern United States. In the northeastern United States, flyspeck incidence is more sporadic in terms of both orchard location and year, indicating that environmental conditions in the Northeast are less favorable to the disease. A small change in canopy microclimate may be useful in the Northeast but have little effect in the Southeast. Second, winter pruning was used in the North Carolina study (14). Winter pruning allows for significant re- growth of new tissue by midsummer, particularly in areas with relatively longer growing seasons. Summer pruning primarily removes new growth at a time that may be critical to flyspeck development.

The mode of action behind the decreased flyspeck incidence in summer-pruned trees appears to be related to a difference in the moisture content of air in the canopy, as indicated by the RH and atmometer data. In vitro studies have shown that $Z$. $j a$ maicensis does not reproduce asexually when RH is below 95\% (13). While it is difficult to measure $\mathrm{RH}$ in this range using electronic sensors, the $\mathrm{RH}$ in the summerpruned trees exceeded $95 \%$ for far less time than it did in the control trees. In addition, the evaporation from spherical ceramic atmometers in the same part of each canopy was far greater in the summer-pruned trees. These data indicate that the moisture content of the air in the summer-pruned trees was generally lower than in the controls and that moisture could evaporate more readily in the summerpruned canopies. However, the hours of leaf wetness were not significantly less in the summer-pruned trees, although more rapid drying might have been expected in those trees based on the atmometer data. Surface moisture, either from dew or rain, may be less important than the moisture content of the air in the tree canopy.

Our experiments in commercial orchards showed that summer pruning significantly decreased flyspeck incidence beyond that accomplished by fungicides alone. In contrast, in our factorial experiment, a single fungicide application or summer pruning each reduced flyspeck incidence by the same amount, but the combination of summer pruning and fungicides did not reduce flyspeck further. The difference between these two observations may be explained in terms of fungicide deposition. In the factorial experiment, the single application of fungicide was made using a high-pressure handgun, and foliage was covered until the solution dripped off the leaf surfaces, regardless of pruning treatment. In commercial blocks, applications are made using relatively low volumes of fungicide solution, from 1,400 to $140 \mathrm{~L} / \mathrm{ha}$. Our results showed that when using this type of application, summer pruning significantly increases the spray deposition in the upper two-thirds of the apple canopy though, surprisingly, it does not appear to allow greater spray penetration into the center of the canopy. Still, improved spray deposition in the upper canopies of summer-pruned trees may also play a role in reducing flyspeck incidence.

\section{ACKNOWLEDGMENTS}

This research was supported in part by grants from the USDA Sustainable Agriculture Research and Education Program and by the Massachusetts Dept. of Food and Agriculture University of Mas- sachusetts Integrated Pest Management Program. We thank David Rosenberger for helpful comments regarding this research and manuscript.

\section{LITERATURE CITED}

1. Altenhofen, J. 1985. A modified atmometer for on-farm evapotranspiration determination. Proc. Conf. Adv. Evapotranspiration. American Society of Agricultural Engineers, Chicago, IL.

2. Anderson, H. W. 1956. Diseases of Fruit Crops. McGraw-Hill, New York.

3. Anonymous. 1967. Apple Sorter's Manual. University of Massachusetts Coop. Ext. Serv. Publ. No. 10.

4. Autio, W. R., and Greene, D. W. 1991. Summer pruning, a continuing look at the benefits. Fruit Notes 56(1):27-28.

5. Brown, E. M., and Sutton, T. B. 1993. Time of infection of Gloeodes pomigena and Schizothyrium pomi on apple in North Carolina and potential control by an eradicant spray program. Plant Dis. 77:451-455.

6. Cooley, D. R., Autio, W. A., and Gamble, J. W. 1992. Second-level apple integrated pest management: The effects of summer pruning and a single fungicide application on flyspeck and sooty blotch. Fruit Notes 57(1):16-17.

7. English, J. T., Thomas, C. S., Marois, J. J., and Gubler, W. D. 1989. Microclimates of grapevine canopies associated with leaf removal and control of Botrytis bunch rot. Phytopathology 79:395-401.

8. Gubler, W. D., Marois, J. J., Bledsoe, A. M and Bettiga, L. J. 1987. Control of Botrytis bunch rot of grape with canopy management. Plant Dis. 71:599-601.

9. Hesler, L. R., and Whetzel, H. H. 1922. Manual of Fruit Diseases. The Macmillan Co., New York.

10. Kirby, R. S. 1954. Relation of rainfall to occurrence of apple scab and sooty blotch. (Abstr.) Phytopathology 44:495.

11. Latham, A. J., and Hollingsworth, M. H. 1973. Incidence and control of sooty blotch and flyspeck of apples in Alabama. Auburn University Agric. Exp. Stn. Circ. 208.

12. McVay, J. R., Walgenbach, J. F., Sikora, E. J. and Sutton, T. B. 1995. A Grower's Guide to Apple Insects and Diseases in the Southeast. Alabama Coop. Ext. Service, Auburn University ANR-838.

13. Ocamb-Basu, C. M., and Sutton, T. B. 1988. Effects of temperature and relative humidity on germination, growth and sporulation of Zygophiala jamaicensis. Phytopathology 78:100-103.

14. Ocamb-Basu, C. M., Sutton, T. B., and Nelson, L. A. 1988. The effects of pruning on incidence and severity of Zygophiala jamaicensis and Gloeodes pomigena infections of apple fruit. Phytopathology 78:1004-1008.

15. Rosenberger, D. A., Engle, C. A., and Meyer, F. W. 1996. Effects of management practices and fungicides on sooty blotch and flyspeck diseases and productivity of Liberty apples. Plant Dis. 80:798-803.

16. Sharp, W. L., and Yoder, K. S. 1985. Correlation between humidity periods and sooty blotch and flyspeck incidence in Virginia apple orchards. (Abstr.) Phytopathology 75:628.

17. Sutton, T. B. 1990. Sooty blotch and flyspeck. Pages 20-22 in: Compendium of Apple and Pear Diseases. A. L. Jones and H. S. Aldwinkle, eds. APS Press, St. Paul, MN

18. Weiss, A., Hipps, L. E., Blad, B. L., and Steadman, J. R. 1980. Comparison of withincanopy microclimate and white mold disease (Sclerotinia sclerotiorum) development in dry edible beans as influenced by canopy structure and irrigation. Agric. Meteorol. 22:11-21. 